\title{
Points for Posts and Badges to Brand Advocates: The Role of Gamification in Consumer Brand Engagement
}

\author{
Elena Vitkauskaite \\ Kaunas University of Technology \\ elena.vitkauskaite@ktu.lt
}

\author{
Rimantas Gatautis \\ Kaunas University of Technology \\ rimantas.gatautis@ktu.lt
}

\begin{abstract}
Gamification became a new attractive way to strengthen relations with consumers for companies and brands. Companies apply different gamification techniques to increase consumer brand engagement. The paper covers the concepts of gamification, the flow state, as well as consumer brand engagement. The assumptions about gamification impact on consumer brand engagement were tested empirically through quantitative analysis of data collected with online questionnaire carried out in Lithuania. Results show a weak but positive relation between gamification and consumer brand engagement. A more integrative method for data analysis, such as structural equation modeling, should be used to assess the model still. The topic could be researched in future with regard to cross-cultural differences, different player types, and different levels of gamification.
\end{abstract}

\section{Introduction}

Gamification was identified as a promising technology by Gartner for several years [17], [18]. The emergence of this technology has lead to a growing number of research and practical solutions. Gamification is applied for a variety of purposes such as user engagement, motivation, education of consumers and employees, innovation management, and personal development [18].

Gamification is perceived as the application of game thinking in non-gaming contexts [12]. The research on gamification demonstrates that in business contexts gamification facilitates intrinsic motivation [13], participation [40], [38], and better consumer experience [15], [19]. These benefits can lead to longlasting customer relations.

Consumer brand engagement is a rather recent concept in the marketing literature [37]. Practitioners perceive consumer brand engagement as the establishment of a strong and enduring bond between brand and consumers based on an ongoing effort of the brand to activate consumers through interaction, shared values, experiential contents, and rewards [33], [16]. Gamification can be extended to establish long-lasting customer relations.

This paper aims to test a model of the impact of gamification on consumer brand engagement. To achieve this, the concepts of gamification, as well as gamification elements, flow, and consumer brand engagement, are described. Based on literature review the assumptions about gamification impact on consumer brand engagement are summarized in a model which was tested in Lithuanian market through an online questionnaire to test the model.

This paper contributes to the research related to the impact of gamification on consumer brand engagement.

\section{Literature review}

\subsection{Gamification and game elements}

The gamification has been used in non-game contexts for a long time [10]. However, practical application of gamification in the physical market used to be rather complicated. Recent ICT developments created favorable conditions for applications of gamification at a large scale and low costs.

One of the first definitions of gamification proposed by Deterding et al. [11] suggested that gamification is based on the use of gamefulness, gameful interaction, and gameful design for the specific purposes. They defined gamification as "the use of game design elements in non-game contexts" [11]. Huotari and Hamari [26] recommend focusing on the user experience, regardless of what form gamified service or activity takes. Werbach and Hunter [39] defined gamification as the adoption of game elements and game development techniques in a non-game context. Considering these views gamification can be 
defined as the use of game elements (such as game mechanics, game dynamics, and game components) in daily non-game context.

As game elements are considered to be the core means to implement gamification, there is a need to identify them as well as their interconnections. Deterding et al. [11] proposed five levels of game design elements. As an alternative practitioners suggested various frameworks enabling gamification of companies' activities - such as Octalysis framework [8], Gamification 2.0 framework [29], and Gamification canvas [28] (see Table 1).

Table 1. Gamification frameworks

\begin{tabular}{|c|c|}
\hline $\begin{array}{l}\text { Gamification } \\
\text { framework }\end{array}$ & Gamification framework description \\
\hline $\begin{array}{l}\text { Levels of } \\
\text { game design } \\
\text { elements [11] }\end{array}$ & $\begin{array}{l}\text { Levels of game design elements include } \\
\text { game interface design patterns, game } \\
\text { design patterns and mechanics, game } \\
\text { design principles and heuristic, game } \\
\text { models, and game design methods. }\end{array}$ \\
\hline $\begin{array}{l}\text { Gamification } \\
\text { pyramid [39] }\end{array}$ & $\begin{array}{l}\text { The framework of game elements } \\
\text { suggesting three levels }- \text { game } \\
\text { dynamics, game mechanics, and game } \\
\text { components. }\end{array}$ \\
\hline $\begin{array}{l}\text { Octalysis } \\
\text { framework [8] }\end{array}$ & $\begin{array}{l}\text { Octalysis framework suggests that } \\
\text { gamification starts from motive } \\
\text { identification and covers eight main } \\
\text { motives. Gamification should consider } \\
\text { different game stages and game player } \\
\text { types. Game elements relate to a } \\
\text { specific motive to play games. }\end{array}$ \\
\hline $\begin{array}{l}\text { Gamification } \\
2.0 \text { framework } \\
{[29]}\end{array}$ & $\begin{array}{l}\text { The framework defines six primary } \\
\text { motives to play games and secondary } \\
\text { motives. The framework suggests game } \\
\text { elements corresponding to specific } \\
\text { motive, evaluation indicators, and } \\
\text { technologies. Game elements might } \\
\text { relate to several motives to play games. }\end{array}$ \\
\hline $\begin{array}{l}\text { Gamification } \\
\text { Canvas [28] }\end{array}$ & $\begin{array}{l}\text { A framework based on Business Model } \\
\text { Canvas [30] and identifying nine } \\
\text { gamification elements. Game elements } \\
\text { were based on MDA model [25]. }\end{array}$ \\
\hline
\end{tabular}

However, the most widely used gamification framework is the gamification pyramid proposed by Werbach and Hunter [39] with focus on game dynamics, game mechanics, and game components. This framework does not only classifies game elements into separate categories but also indicates interconnections between game elements of different categories. Therefore, this framework was selected for the study and is further presented in more detail.

Dynamics covers the broadest aspects of a gamification. Some elements of this category [39]:
- Constraints (certain restrictions or forced withdrawals);

- Emotions (curiosity, competitiveness, frustration, happiness);

- Narrative (consistent, constant, continuous storyline);

- Progression (user as a player growth and improvement); and

- Relationships (social interaction creates feelings of friendship, status, altruism).

Mechanics cover the basic processes of a gamified system. They drive and maintain user engagement with the content of a gamified activity.

- Exploring (possibilities to explore the game/game world freely);

- Collection (acquisition of useful or collectible game resources);

- Competition (possibility for a player or a group of players to win while other loose);

- Status acquisition (conditions that have to be met for players to reach higher level);

- Collaboration (players must act together to achieve a common goal);

- Challenge (quizzes, quests and other tasks that require effort to solve it); and

- Development (conditions allowing players to acquire new knowledge or skills).

Components are more specific elements compared to Dynamics or Mechanics. These elements lead to actual solutions that can be used to gamify the activity of interest. Components make up the largest group of game elements. Some elements of this category:

- Points (usually a numerical representation of rewarding the player for activities carried out in a game);

- Badges (the visual representation of player achievements indicating that player reached specific status or level)

- Leaderboards (listing of players based on their performance in the game)

- Levels (a system of advancing in the game by collecting a certain amount of points or carrying out specific actions)

- Rewards (benefits or (game) assets given to a player based on his achievement in game); and

- Feedback (providing the player with information about his performance in a game).

Although there is a larger number of elements used for gamification purposes than examples listed above, literature analysis revealed that researchers look into few of them, and some game elements were researched more than others by gamification scholars. Therefore, examples cover the most often researched game elements (based on [39] [4] [3] [34]). 
Various combinations of game elements can be used to gamify business activities to drive desired actions of consumers. However, "gamification is not about slapping points and badges onto an activity and expecting it to magically become more engaging" [5]. Therefore, for companies using gamification, it is important to understand if the gamification efforts are successful. The research on video games associates successful video games with the state of flow [20] [21]. Therefore, flow state was further studied as a possible mediator.

\subsection{Gamification and flow}

According to various researchers and practitioners flow is an important construct in gamification research [1], [10], [20], [21], [39].

Csikszentmihalyi [9] proposed the concept of flow by defining it as a "state of concentration or complete absorption with the activity at hand and the situation. It is a state in which people are so involved in an activity that nothing else seems to matter". Flow is characterized by the balance between challenges and skills. Otherwise, the user will experience boredom or anxiety. In gamification, as in games, such balance can be achieved through designing increasingly challenging experience for consumers or players by use of various game elements.

Csikszentmihalyi [9] identified nine important flow characteristics:

- Clear objectives

- Immediate feedback

- Equilibrium between the level of challenge and personal skill

- Merging of action and awareness

- Focused concentration

- Sense of potential control

- Loss of self-consciousness

- Time distortion

- Autotelic or self-rewarding experience

Flow can be interpreted as a mono-dimensional or multidimensional construct. Hoffman and Novak [22] suggested to analyze flow as a multi-dimensional construct and proposed that every dimension of flow should be measured independently. However, researchers, interpreting flow as mono-dimensional, treat flow as an independent construct as well as constructs of antecedents and gamification results.

To the date, there are few empirical studies on the relation between gamification, flow state, and consumer behavior. However, few of the first studies into this area indicate that flow state is positively related to intention to purchase goods promotion of which was gamified [2], [36].

\subsection{Consumer brand engagement}

Hollebeek [23] defined consumer brand engagement as "the level of a customer's motivational, brand-related, and context-dependent state of mind characterized by specific levels of cognitive, emotional, and behavioral activity in brand interactions." Javornik and Mandelli [27] identified four perspectives for the main research streams of the customer engagement in the academic literature:

- Behavioral perspective

- Psychological (cognitive and affective) perspective

- Multidimensional perspective

- Social perspective

Cognitive, emotional and behavioral dimensions are most commonly identified in scientific literature related to consumer engagement studies [23], [24]:

- Cognitive dimension: consumer's level of engagement object related through processing, concentration, and interest in the specific object (business enterprise, brand, online social network, brand community).

- Emotional dimension: a state of emotional activity also known as the feeling of inspiration or pride related to and caused by engagement object.

- Behavioral dimension: a state of consumer behavior related to engagement object and understood as an endeavor, and the energy given for interaction.

It is important to note that online the experience of consumer gains an important role. According to Calder et al. [6], the fundamental insight is that engagement comes from experiencing websites, social networking platforms or applications to deliver gamified activities. Consumer experience in using these tools refers to consumer engagement. According to Calder et al. [6], online consumer engagement can be understood to its fullest only after a thorough examination of different experiences that the consumer gets during the interaction with the site, social networking platforms or application.

Consumer experiences could be created and delivered through various game elements and combinations of game elements. Robson et al. [32] suggested that gamified experience can be analyzed through perspectives of participation and connection:

- Participation (active vs. passive) perspective. Player participation describes the extent to which the individual is either passively involved in the experience or actively contributes to it. 
- Connection (absorbed vs. immersive) perspective. Player connection describes the type of environmental relationship that unites the individual with the experience. In absorption, the experience unfolds before the person and occupies the person's mind, whereas in immersion a person becomes part of the experience itself.

The gamified engagement is important as according to Fischer [14], engaged consumers tend to bring together a group of other consumers that have identical or very similar interests. The engaged consumers tend to become loyal, act as brand advocates and more actively participate in various initiatives of a brand.

\section{Research model}

The research aims to identify the gamification impact on consumer brand engagement. Therefore, the core assumption tested was that gamification, or use of a combination of game elements, within business activity involving consumers should lead to higher brand engagement. This assumption has lead to the first hypothesis:

$\mathbf{H}_{1}$ - gamification of a business activity positively impacts consumer brand engagement

Based on literature review presented above, it was also assumed that gamification should lead to higher consumer engagement with the gamified activity and that such engagement can be expressed and measured through the flow state ([1], [10], [20], [21], [39]). Besides, it was assumed that consumers who are more engaged with gamified business activities (i.e., get into the flow state) could be more likely to have higher brand engagement (e.g. [14]). Therefore, it has lead to following hypotheses:

$\mathbf{H}_{\mathbf{2}}$ - gamification positively impacts flow state achieved while taking part in business activity

$\mathbf{H}_{2 \mathbf{B}}$ - flow state achieved while taking part in gamified business activity positively impacts consumer brand engagement

The research model was constructed by following above assumptions (see Figure 1).

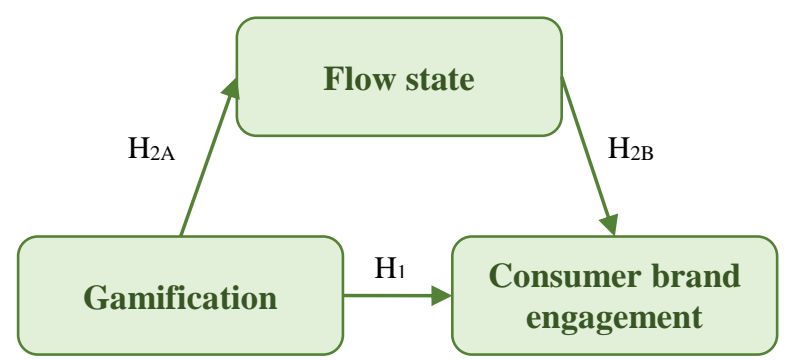

Figure 1. Conceptual research model
As gamification is perceived as the use of game elements (such as game mechanics, game dynamics, and game components) in daily non-game context, within this study, this construct regards specific game elements used for gamification of a business activity.

The flow state is an intermediary outcome of gamification, and therefore, a mediator between gamification and consumer brand engagement. For this research, flow state was treated as a mono-dimensional construct.

Consumer brand engagement is an outcome of the gamified activity tested within this research. It was treated as multi-dimensional construct including cognitive, emotional and behavioral dimensions.

\section{Research method}

A quantitative research approach is a fitting option to test the hypotheses mentioned above. Therefore, the quantitative online survey method was selected for primary data collection. The study covered a wider array of questions, but only aspects related to abovepresented research model are discussed in detail in this paper. People, who have engaged in some business activities through gamification anytime in the past six months were the population of interest for this research.

The questionnaire was developed based on the nature of information needed. At the beginning of the questionnaire, the explanation was provided on what researchers mean by the term of "gamification." Few example descriptions of gamified business activities were included in the description mentioning specific brands that gamified their activities in Lithuanian market recently. Respondents were asked to remember if in the past six months they were involved in gamified activities and to name / briefly describe them.

Item statements related to the constructs covered in this research are listed in Table 2. For the gamification, two separate scales were employed to cover game mechanics and game components. Scale for measuring game mechanics consisted of 7 items and scale for game components consisted of 5 items; both were based on literature (see section 2.1). Game elements of game dynamics category were not covered in this research as those game elements were deemed too difficult to assess by surveying respondents about past involvement in gamified activities. The flow state was treated as a mono-dimensional construct, and the scale for measuring it includes seven items: five items adapted from Choi and Kim [7], and two from the short flow scale from Rheinberg, Vollmeyer and Engeser [31]. 
Table 2. Item statements used

\begin{tabular}{l} 
Construct/ Item statements \\
\hline Gamification \\
\hline Game mechanics \\
1. Games that allow exploration, to learn \\
more, encouraging self-education \\
2. Games that encourage collecting of \\
something \\
3. Games that encourage healthy competition \\
with other players \\
4. Games that need lots of effort to win and \\
become a leader \\
5. Games where players play in teams, create \\
their community \\
6. Games with serious challenges \\
7. Games that educate and develop some \\
skills
\end{tabular}

Game components

1. Points that reflect progress in the game

2. Leaderboards (visual representation of achievements in comparison with other players)

3. Achievements/badges (implementation of certain quests, visual representation of accomplishments)

4. Levels - progressing difficulty of the game environment

5. Feedback - provision of information on your actions in the game

\begin{tabular}{lll}
\hline \multicolumn{2}{l}{ Flow state } \\
\hline 1. I did not notice time passing & {$[31]$} \\
2. I was entirely absorbed in playing the & {$[7]$} \\
& game & {$[31]$} \\
3. I was completely lost in thought & {$[7]$} \\
4. Playing the game was interesting in itself & {$[7]$} \\
5. Playing the game was fun & {$[7]$} \\
6. I felt curious while playing the game & {$[7]$} \\
7. I was in control of the game that I was &
\end{tabular}

Consumer brand engagement

Cognitive

1. I pay a lot of attention to anything about this brand/company

2. Anything related to this brand/company grabs my attention

7]

3. I like learning more about this brand/company

\section{Emotional}

4. I feel good when I use this brand/ company products/services

5. I am passionate about this brand/company [35]

6. I love this brand/company

7. Using the brand/ company products/services makes me happy

8. I' $\mathrm{m}$ proud to use this brand

\begin{tabular}{|c|c|}
\hline Construct/ Item statements & Source \\
\hline \multicolumn{2}{|l|}{ Behavioural } \\
\hline $\begin{array}{l}\text { 9. This brand is one of the brands I usually } \\
\text { use when I use products from the same } \\
\text { category }\end{array}$ & [24] \\
\hline $\begin{array}{l}\text { 10. In general, I like to get involved in } \\
\text { brand/company community discussions }\end{array}$ & {$[35]$} \\
\hline $\begin{array}{l}\text { 11. I often participate in activities of the } \\
\text { brand/company community }\end{array}$ & {$[35]$} \\
\hline $\begin{array}{l}\text { 12. In general, I thoroughly enjoy exchanging } \\
\text { ideas with other people in the } \\
\text { brand/company community }\end{array}$ & [35] \\
\hline
\end{tabular}

The scale for consumer brand engagement includes 11 items, adapted from So, King and Sparks [35] and Hollebeek, Glynn and Brodie [24]. Three items of this scale reflect the cognitive brand engagement dimension, five items cover the emotional dimension and remaining three items represent the behavioral dimension. Cronbach alpha coefficients show high internal consistency.

A respondent panel of a market research company was used for data collection. The respondents for this survey were selected by non-probability convenience sampling method, - an invitation to participate in the survey was sent to all registered respondent members of the market research company contracted. The data collection was carried out in 2015.

Table 3. Demographic characteristics of respondents

\begin{tabular}{ll|c|c}
\hline \multicolumn{2}{l|}{ Characteristic } & $\boldsymbol{N}[\mathbf{3 4 7}]$ & $\boldsymbol{\%}[\mathbf{1 0 0}]$ \\
\hline \multirow{2}{*}{ Gender } & Male & 87 & 25.1 \\
& Female & 260 & 74.9 \\
\hline \multirow{2}{*}{ Age } & 25 years or younger & 69 & 19.9 \\
& 26-35 years & 216 & 62.2 \\
& older than 35 & 62 & 17.9 \\
\hline
\end{tabular}

Answers from 749 respondents were received in the online survey. Less than half of them (46.3\%) stated they were engaged in some gamified business activities though. Therefore, data analysis and the research findings are based on data from 347 respondents (see Table 3). Females were dominating (about 75\%) among those surveyed, and more than $62 \%$ of respondents were of age between 26 and 35 years old.

\section{Empirical research results}

Descriptive statistics on game elements are summarized in Tables 4 and 5. Survey participants found attractive the gamified business activities having development function, motivating to explore, acquire knowledge, and develop (Table 4). The least attractive are gamified business activities encouraging to collect. 
In respect to game components, respondents evaluated levels and points as the most important (see Table 5).

Table 4. Attractiveness of different game mechanics

\begin{tabular}{l|c|c}
\hline Item & Mean & Standard deviation \\
\hline Development & 4.32 & 0.655 \\
\hline Exploration & 4.24 & 0.736 \\
\hline Challenge & 3.66 & 0.839 \\
\hline Competition & 3.62 & 0.821 \\
\hline Status achievement & 3.21 & 0.934 \\
\hline Collaboration & 3.12 & 1.023 \\
\hline Collection & 2.98 & 1.001 \\
\hline $\mathrm{N}-324$ &
\end{tabular}

Table 5. Importance of game components

\begin{tabular}{l|c|c}
\hline Item & Mean & Standard deviation \\
\hline Levels & 3.90 & 0.721 \\
\hline Points & 3.85 & 0.745 \\
\hline Feedback / reward & 3.76 & 0.817 \\
\hline Achievement / badges & 3.65 & 0.865 \\
\hline Leader board & 3.56 & 0.973 \\
\hline $\mathrm{N}-331$
\end{tabular}

Table 6. Measures of consumer brand engagement

\begin{tabular}{l|c|c}
\hline Item & Mean & Standard deviation \\
\hline Cognitive engagement & 3.05 & 0.862 \\
\hline Emotional engagement & 3.02 & 0.800 \\
\hline Behavioral engagement & 2.66 & 0.934 \\
\hline $\begin{array}{l}\text { Consumer brand } \\
\text { engagement }\end{array}$ & 2.91 & 0.778 \\
\hline
\end{tabular}

$\mathrm{N}-329$

Analysis of flow state indicated high respondent engagement with gamified business activities $(M=$ 3.77, $S D=0.567)$.

Descriptive statistics on brand engagement presented in Table 6 shows that overall consumer brand engagement is relatively low. Respondents on average evaluated items related to cognitive engagement most positively. The emotional engagement was evaluated nearly as high. Meanwhile, items of behavioral engagement were assessed less positive.

It is evident that respondents found the gamified activities far more engaging than they feel connected to the brand of the business which offered the gamified experience to them.

The hypothesis $\mathbf{H}_{\mathbf{2}}$ of of gamification leading to flow state was checked by analyzing the correlation between gamification and flow state. Results of this analysis prove the positive statistically relevant relation between these constructs, the relation is of average strength though (see Table 7).

Table 7. Correlation between gamification and flow

\begin{tabular}{|l|c|}
\multicolumn{1}{c|}{ state } \\
\cline { 2 - 2 } \multicolumn{1}{c|}{} & Flow state \\
\hline Game mechanics & $0.393^{* *}$ \\
\hline Game components & $0.392^{* *}$ \\
\hline Overall gamification & $0.443^{* *}$ \\
\hline$* * p<0.001$, Spearman's rho correlation coefficient
\end{tabular}

Regression analysis was applied to check flow state impact on consumer brand engagement. Flow state was used as an independent variable and consumer engagement - dependent variable. However, determination coefficient $R^{2}=0.096$ of regression model $(F(1.326)=34.650 ; p<0.000)$ was way smaller than recommended minimal interpretable value $\left(R^{2}<\right.$ 0.2). Therefore, hypothesis $\mathbf{H}_{\mathbf{2}}$ was supported by evidence, though the relation is found to be weak.

To explore direct relations between gamification and consumer brand engagement, without mediation impact of flow state, correlation analysis was performed. Correlation between the combined constructs of gamification and consumer brand engagement has a weak positive significant relation ( $r$ $=0.26, p<0.001)$. Both game mechanics and game components were found to be positively related with consumer brand engagement $(r=0.20, p<0.001$ and $r$ $=0.24, p<0.001$, respectively), though the relation found was weak. Correlation between separate game gamification and consumer engagement dimensions was found to have positive, but weak relations (see Table 8). The strongest relation was found between gamification and cognitive engagement $(r=0.28, p<$ $0.001)$, and the weakest - between gamification and behavioral engagement $(r=0.17, p<0.001)$. Thus the overall assumption of research presented in this paper of gamification positively impacting consumer brand engagement can be confirmed. Although the relation between those constructs is weak, it supports hypothesis $\mathbf{H}_{1}$. In addition, game components were found to have a bit stronger relationship with consumer brand engagement and its dimensions compared to game mechanics.

Therefore, in order to test the impact of different game mechanics elements on consumer brand engagement, multiply regression was performed by taking separate game mechanics elements as independent variables and consumer brand engagement as dependent. Using the enter method, it was found that the game mechanics elements explained $24.3 \%$ of the 
Table 8. Correlation between gamification and consumer brand engagement

\begin{tabular}{|l|c|c|c|c|c|c|c|}
\cline { 2 - 8 } \multicolumn{1}{c|}{} & $\begin{array}{c}\text { Gamifi- } \\
\text { cation }\end{array}$ & $\begin{array}{c}\text { Game } \\
\text { mechanics }\end{array}$ & $\begin{array}{c}\text { Game } \\
\text { components }\end{array}$ & $\begin{array}{c}\text { Consumer } \\
\text { engagement }\end{array}$ & Cognitive & Emotional & Behavioral \\
\hline Gamification & 1.000 & $0.837^{* *}$ & $0.884^{* *}$ & $0.255^{* *}$ & $0.275^{* *}$ & $0.256^{* *}$ & $0.173^{* *}$ \\
\hline Game mechanics & & 1.000 & $0.490^{* *}$ & $0.202^{* *}$ & $0.210^{* *}$ & $0.210^{* *}$ & $0.150^{* *}$ \\
\hline Game components & & 1.000 & $0.237^{* *}$ & $0.265^{* *}$ & $0.239^{* *}$ & $0.146^{* *}$ \\
\hline $\begin{array}{l}\text { Consumer } \\
\text { engagement }\end{array}$ & & & & 1.000 & $0.890^{* *}$ & $0.880^{* *}$ & $0.878^{* *}$ \\
\hline Cognitive & & & & & 1.000 & $0.753^{* *}$ & $0.641^{* *}$ \\
\hline Emotional & & & & & & 1.000 & $0.658^{* *}$ \\
\hline Behavioral & & & & & & & 1.000 \\
\hline
\end{tabular}

variance in consumer brand engagement $\left(R^{2}=0.243, F\right.$ $(7,311)=14.264, p<0.001)$. However, the analysis of coefficients showed that only three out of seven elements significantly predicted the value of consumer brand engagement, namely, status achievement $(\beta=$ $0.252, p<0.001)$, collection $(\beta=0.208, p<0.000)$, and collaboration $(\beta=0.182, p<0.01)$. Such elements as exploration $(\beta=-0.020, p=$ n.s. $)$, development $(\beta=$ $-0.114, p=$ n.s. $)$, challenge $(\beta=-0.009, p=$ n.s. $)$ and competition $(\beta=0.033, p=$ n.s. $)$ did not have significant impact on consumer brand engagement.

To test the impact of different game components on consumer brand engagement, one more multiply regression was performed by taking separate game components as independent variables and consumer brand engagement as dependent variable. Using the enter method, it has been found that game components explained $10.3 \%$ of the variance in consumer brand engagement $\left(R^{2}=0.103, F(5,320)=7.358, p<0.00\right)$. The analysis of coefficients showed that only one component (leaderboards) had significant influence on the consumer brand engagement $(\beta=0.274, p<$ $0.001)$. Other game components, such as points $(\beta=-$ $0.027, p=$ n.s. $)$, achievements/badges $(\beta=0.096, p=$ n.s.), levels $(\beta=-0.082, p=$ n.s. $)$ and feedback/rewards $(\beta=0.043, p=$ n.s. $)$ did not significantly predict value of consumer brand engagement.

Table 9. The coefficients of multiply regression model

\begin{tabular}{|c|c|c|c|c|c|}
\hline & \multicolumn{2}{|c|}{ Unstandardized Coefficients } & \multirow{2}{*}{$\begin{array}{c}\begin{array}{c}\text { Standardized } \\
\text { Coefficients }\end{array} \\
\text { Beta } \\
\end{array}$} & \multirow{2}{*}{$\mathbf{t}$} & \multirow{2}{*}{ Sig. } \\
\hline & B & Std. Error & & & \\
\hline (Constant) & 1.665 & 0.312 & & 5.342 & 0.000 \\
\hline Status achievement & 0.177 & 0.047 & 0.212 & 3.783 & 0.000 \\
\hline Collection & 0.144 & 0.041 & 0.183 & 3.514 & 0.001 \\
\hline Leaderboard & 0.145 & 0.043 & 0.178 & 3.366 & 0.001 \\
\hline Collaboration & 0.131 & 0.043 & 0.169 & 3.010 & 0.003 \\
\hline Development & -0.155 & 0.059 & 0.130 & -2.633 & 0.009 \\
\hline
\end{tabular}

Notes: Dependent Variable: Consumer brand engagement
As two multiply regression models allowed to identify the game mechanics and game components that have a significant impact on consumer brand engagement, to reveal the impact of each of them, one more regression analysis was performed. This time by using the stepwise method, the authors took separate game mechanics and components as independent variables and consumer brand engagement as the dependent variable. The regression with stepwise method resulted in 5 models, and the best of them indicated that five predictors explained $26.1 \%$ of the variance in consumer brand engagement $\left(R^{2}=0.261, F\right.$ $(5,304)=21.485, p<0.001)$. Status achievement had the strongest significant impact $(\beta=0.212, p<0.001)$; meanwhile, the development had significant negative influence on consumer brand engagement $(\beta=-0.130$, $\mathrm{p}<0.01$ ) (Table 9).

As consumer brand engagement was conceptualized as consisting of three dimensions, the impact of different game mechanics and components on cognitive, emotional and behavioral engagement was explored. Three more models of multiply regression were developed with each of consumer brand engagement dimension as the dependent variable. The results of regression analysis are provided in Table 10. 
Table 10. The results of multiply regression with dimensions of consumer engagement as dependent variables

\begin{tabular}{|c|c|c|c|c|c|c|c|}
\hline \multirow[t]{2}{*}{ Model } & \multirow{2}{*}{$\begin{array}{l}\text { Dependent } \\
\text { variable }\end{array}$} & \multirow[t]{2}{*}{ R square } & \multicolumn{2}{|c|}{ ANOVA } & \multirow[t]{2}{*}{ Predictors } & \multirow[t]{2}{*}{ Beta } & \multirow[t]{2}{*}{ Sig. } \\
\hline & & & F (df) & Sig. & & & \\
\hline 1 & $\begin{array}{l}\text { Cognitive } \\
\text { engagement }\end{array}$ & 0.188 & $\begin{array}{l}17.561 \\
(4,303)\end{array}$ & 0.000 & $\begin{array}{l}\text { Leaderboard } \\
\text { Collection } \\
\text { Collaboration } \\
\text { Status achievement }\end{array}$ & $\begin{array}{l}0.205 \\
0.186 \\
0.129 \\
0.124\end{array}$ & $\begin{array}{l}0.000 \\
0.001 \\
0.030 \\
0.036\end{array}$ \\
\hline 2 & $\begin{array}{l}\text { Emotional } \\
\text { engagement }\end{array}$ & 0.191 & $\begin{array}{l}24.095 \\
(3,306)\end{array}$ & 0.000 & $\begin{array}{l}\text { Status achievement } \\
\text { Collection } \\
\text { Leaderboard }\end{array}$ & $\begin{array}{l}0.251 \\
0.199 \\
0.172\end{array}$ & $\begin{array}{l}0.000 \\
0.000 \\
0.002\end{array}$ \\
\hline 3 & $\begin{array}{l}\text { Behavioral } \\
\text { engagement }\end{array}$ & 0.269 & $\begin{array}{l}18.292 \\
(6,298)\end{array}$ & 0.000 & $\begin{array}{l}\text { Status achievement } \\
\text { Collaboration } \\
\text { Development } \\
\text { Collection } \\
\text { Leaderboard } \\
\text { Levels }\end{array}$ & $\begin{array}{l}0.235 \\
0.208 \\
-0.108 \\
0.142 \\
0.144 \\
-0.113\end{array}$ & $\begin{array}{l}0.000 \\
0.000 \\
0.001 \\
0.008 \\
0.008 \\
0.038\end{array}$ \\
\hline
\end{tabular}

The results showed that only in case of behavioral engagement as the dependent variable, it is possible to talk about meaningful interpretation, as $\mathrm{R}$ square, in this instance, is bigger than $0.2\left(R^{2}=0.269\right)$, which means that the selected predictors explain $26.9 \%$ of the variance in behavioral engagement. The analysis of beta coefficients showed that such game mechanics as status achievement, collaboration and collection can significantly predict positive behavioral engagement of consumers; meanwhile, the game mechanics of development has a negative impact on the consumer behavioral engagement. Results showed that two game components significantly predicted behavioral engagement, i.e., leaderboards had the positive impact and levels had the negative impact.

\section{Discussion and conclusions}

Gamification is an increasingly popular mean to establish better relations with consumers and develop consumer engagement. Gamification can be defined as the use of game elements in daily situations which are not related to games. The most popular approach to gamification is the gamification pyramid approach proposed by Werbach and Hunter [39]. Gamification pyramid concept defines key game element categories: game dynamics, game mechanics, and game components.

The flow state is a possible indicator to evaluate whether gamification of business activity was implemented successfully. Studies to date indicate that flow has a positive relation to desired customer behavior.
Gamification is regarded as successful mean to facilitate consumer brand engagement. Consumer brand engagement is considered as multi-dimensional construct defined through three dimensions cognitive, behavioral and emotional. Gamification creates engaging experience which leads to beneficial consumer behavior towards a company.

Literature review allowed authors to suggest a model of gamification impact on consumer brand engagement. Gamification can be expressed through the use of game elements. It was assumed that successful gamification leads to flow state and flow results in higher consumer brand engagement.

These assumptions were empirically tested with an online survey in Lithuanian market. The findings support the assumptions only partly. Gamification was found to have a significant correlation with flow state, though of average strength. A positive correlation was also found between constructs of gamification and consumer brand engagement, though the relation was found to be weak. Results of regression analysis indicated positive relations between constructs of gamification and flow, flow and consumer brand engagement, as well as gamification and consumer brand engagement, but all these relations are weak. Analysis of the impact of game elements on specific brand engagement dimensions showed that game elements have a different relationship with consumer brand engagement. Such game mechanics as status achievement, collaboration, and collection can significantly predict positive behavioral engagement. Meanwhile, the development had a negative impact on the behavioral engagement. Two game components significantly predicted behavioral engagement as well, 
i.e., leaderboards had the positive impact and levels had the negative impact.

Possible limitations of the research presented herein could be related to the several factors. First of all, the choice of researchers not to seek answers about specific gamified experiences might have resulted in diffused answers, especially in cases respondents recognized they participated in several different gamified experiences, with some of which they were probably engaging a while ago. Having answers about specific gamified activity with more recent participation experience could produce more meaningful results. This would also enable researchers to take into account additional characteristics of gamified activities and therefore to provide deeper insights. Another possible issue relates to the fact that characteristics of the respondents available in the panel were unknown to the authors. $74.9 \%$ of respondents of the current research were women, and such proportion is not representative of the general population. However, if this is representative of gender distribution within the panel, there might be other panel population characteristics that might be of importance to properly interpret the results, but remain unknown to the authors. Last, but not least, as respondents were from Lithuania only, results might not match the attitudes of customers with different cultural backgrounds.

Besides the limitations, a more integrative method for data analysis, such as structural equation modeling, should be used to assess the complete model.

The future research on the impact of gamification on brand engagement could take into account such aspects as cross-cultural differences, different player types and their motivation to engage in gamified business activities as well as different levels of gamification.

\section{References}

[1] Aparicio, A. F., F. L. G. Vela, J. L. G. Sánchez, and J. L. I. Montes, "Analysis and application of gamification", In Proceedings of the 13th International Conference on Interacción Persona-Ordenador, ACM, 2012 No. 17.

[2] Bittner, J. V., and J. Shipper, "Motivational Effects and Age Differences of Gamification in Product Advertising", Journal of Consumer Marketing, 2014, 31(5), pp. 391-400.

[3] Blohm, I., and J. M. Leimeister, "Gamification", Business \& Information Systems Engineering, 2013, 5(4), pp. 275278.

[4] Bunchball, Gamification 101: An Introduction to the Use of Game Dynamics to Influence Behavior, 2010, accessed 24/09/2013, on http://www.bunchball.com/sites/default/files/ downloads/gamification101.pdf
[5] Burke, B., "Why Gamification's Not a Game", In The Wall Street Journal, 2014, accessed 8/5/2015 on http://blogs.wsj.com/cio/2014/05/06/why-gamifications-nota-game/

[6] Calder, B. J., E. C. Malthouse, and U. Schaedel, "An Experimental Study of the Relationship between Online Engagement and Advertising Effectiveness", Journal of Interactive Marketing, 2009, 23(4), pp. 321-331.

[7] Choi, D., and J. Kim, "Why People Continue to Play Online Games: In Search of Critical Design Factors to Increase Customer Loyalty to Online Contents", Cyberpsychology \& Behavior, 2004, 7(1), pp. 11-24.

[8] Chou, Y.-K, Actionable Gamification: Beyond Points, Badges, and Leaderboards, Octalysis Media, 2015.

[9] Csikszentmihalyi, M., Flow: The Psychology of Optimal Experience, New York: Harper and Row, 1990.

[10] Deterding, S., "Eudaimonic Design, or: Six Invitations to Rethink Gamification", In M. Fuchs et al., eds. Rethinking Gamification. Lüneburg: meson press, 2014, pp. 305-323.

[11] Deterding, S., D. Dixon, R. Khaled, and L. Nacke, "From game design elements to gamefulness: defining "gamification", In: Proceedings of the 15th International Academic MindTrek Conference: Envisioning Future Media Environments, ACM, Tampere, Finland, 2011, pp. 9-15.

[12] Deterding, S., R. Khaled, L. E. Nacke, and D. Dixon, "Gamification: toward a definition", In: Proceedings of the 2011 annual conference extended abstracts on Human factors in computing systems - CHI EA '11. New York, New York: ACM Press, 2011.

[13] Domínguez, A., J. Saenz-de-Navarrete, L. de-Marcos, L. Fernández-Sanz, C. Pagés, and J.-J. Martínez-Herráiz, "Gamifying learning experiences: practical implications and outcomes", Computers \& Education, 2013, 63, pp. 380-392.

[14] Fischer, L., Exploring online engagement through the lens of PR theory: Investigating its communal orientation in a case study on edelman, Doctoral dissertation, Leed Metropolitan University, 2011.

[15] Flatla, D. R., C. Gutwin, L. E. Nacke, S. Bateman, and R. L. Mandryk, "Calibration games: making calibration tasks enjoyable by adding motivating game elements", In Proceedings of the 24th annual ACM symposium on User interface software and technology, ACM, 2011, pp. 403-412.

[16] Gambetti, R. C., G. Graffigna, and S. Biraghi, "The Grounded Theory approach to consumer-brand engagement", International Journal of Market Research, 2012, 54(5), pp. 659-687.

[17] Gartner, Gartner Predicts Over 70 Percent of Global 2000 Organisations Will Have at Least One Gamified 
Application by 2014, 2011, accessed 2014/01/15, on http://www.gartner.com/newsroom/id/1844115

[18] Gartner, Gartner Says by 2014, 80 Percent of Current Gamified Applications Will Fail to Meet Business Objectives Primarily Due to Poor Design, 2012, accessed 2015/07/28 on http://www.gartner.com/newsroom/id/2251015

[19] Gnauk, B., L. Dannecker, and M. Hahmann, "Leveraging gamification in demand dispatch systems", In: Proceedings of the 2012 Joint EDBT/ICDT Workshops, ACM, Berlin, Germany, 2012, pp. 103-110.

[20] Groh, F., "Gamification: State of the Art Definition and Utilization", In Proceedings of the 4th Seminar on Research Trends in Media Informatics, 2012, pp. 39-46.

[21] Herzig, P., S. Strahringer, and M. Ameling, "Gamification of ERP Systems-Exploring Gamification Effects on User Acceptance Constructs", In Multikonferenz Wirtschaftsinformatik, 2012, pp. 793-804.

[22] Hoffman, D. L., and T. P. Novak, "Flow Online: Lessons Learned and Future Prospects", Journal of Interactive Marketing, 2009, 23(1), pp. 23-34.

[23] Hollebeek, L., "Exploring customer brand engagement: definition and themes", Journal of Strategic Marketing, 2011, 19(7), pp. 555-573.

[24] Hollebeek, L. D., M. S. Glynn, and R. J. Brodie, "Consumer Brand Engagement in Social Media: Conceptualization, Scale Development and Validation", Journal of Interactive Marketing, 2014, 28(2), pp. 149-165.

[25] Hunicke, R., M. LeBlanc, and R. Zubek, "MDA: A formal approach to game design and game research", In Proceedings of the AAAI Workshop on Challenges in Game AI (Vol. 4), 2004.

[26] Huotari, K., and J. Hamari, "Defining gamification: a service marketing perspective", In Proceeding of the $16^{\text {th }}$ International Academic MindTrek Conference on MindTrek'12, New York, USA: ACM Press, 2012, p. 17-22.

[27] Javornik, A., and A. Mandelli, "Research categories in studying customer engagement", In AM2013 Academy of Marketing Conference, Cardiff, 2013.

[28] Jiménez, S., Gamification Model Canvas. Game On lab, 2014, accessed 2015/07/28 on http://www.gameonlab.com/canvas/
[29] Killian, E., Gamification 2.0 - A Concept. Eamonn Killian, 2013.

[30] Osterwalder, A., and Y. Pigneur, Business model generation: a handbook for visionaries, game changers, and challengers, John Wiley \& Sons, 2010.

[31] Rheinberg, F., R. Vollmeyer, and S. Engeser, Die Erfassung des Flow-Erlebens, na, 2003.

[32] Robson, K., K. Plangger, J. Kietzmann, I. McCarthy, and L. Pitt, "Understanding Gamification of Consumer Experiences", Advances in Consumer Research, 2014, 42, pp. 352-356.

[33] Schultz, D. E., "Focus on brand changes rules of engagement", Marketing News, 15 August 2007, pp. 7-8.

[34] Seaborn, K., and D. I. Fels, "Gamification in theory and action: A survey", International Journal of Human-Computer Studies, 2015, 74, February, pp. 14-31.

[35] So, K. K. F., C. King, and B. Sparks, "Customer Engagement With Tourism Brands Scale Development and Validation", Journal of Hospitality \& Tourism Research, 2014, 38(3), pp. 304-329.

[36] Terlutter, R., and M. L. Capella, "The Gamification of Advertising: Analysis and Research Directions of In-Game Advertising, Advergames, and Advertising in Social Network Games", Journal of Advertising, 2013, 42(2-3), pp. 95-112.

[37] Vivek, S. D., S. E. Beatty, and R. M. Morgan, "Consumer engagement: exploring customer relationships beyond purchase", Journal of Marketing Theory and Practice, 2011, 20(2), pp. 122-146.

[38] Von Ahn, L., and L. Dabbish, "Designing games with a purpose", In Communications of the ACM, 2008, 51(8), pp. 58-67.

[39] Werbach, K., and D. Hunter, For the Win: How game thinking can revolutionize your business, Wharton Digital Press, 2012.

[40] Witt, M., C. Scheiner, and S. Robra-Bissantz, "Gamification of online idea competitions: insights from an explorative case", In: Proceedings of INFORMA-TIK 2011Informatik Schafft Communities, Lecture Notes in Informatics, Berlin, Germany, 2011. 